NAMA : NUR AMALIA MAGFIRA A

KELAS : HTN E 2020

NIM : 10200120198

\title{
RESUME
}

\section{PARTAI POLITIK DAN PEMILIHAN UMUM}

\section{A. Partai politik}

Political party is an autonomous group of citizens having the porpose of making nominations and contesting election in hope of gaining control over gavernmental power through the capture of public offices and the organization of the government.Partai politik adalah kelompok otonom dari warga negara, memiliki kegunaan dalam membuat nominasi-nominasi dan peserta pemilu, memiliki keinginan memandu pengawasan pada kekuasaan pemerintahan terus merebut jabatan-jabatan publik dalam organisasi pemerintahan.

Menurut Miriam Budiardjo, partai politik merupakan suatu kelompok terorganisir yang anggota-anggotanya mempunyai orientasi, nilai-nilai, dancita-cita yang sama. Tujuan kelompok ini adalah untuk memperoleh kekuasaan politik dan merebut kedudukan politik (biasanya) dengan cara konstitusional untuk melaksanakan programnya.Begitu juga menurut Carl J. Friedrich, partai politik adalah sekelompok manusia yang terorganisir secara stabil dengan tujuan merebut atau mempertahankan pengusaan terhadap pemerintahan bagi pimpinan partainya, dan berdasarkan penguasaan ini, memberikan pada anggota partainya kemanfaatan yang bersifat adil serta material.37 Sementara menurut Sigmund Neuman, partai politik adalah organisasi dan aktivisaktivis politik yang berusaha untuk menguasai kekuasaan pemerintahan serta merebut dukungan rakyat melalui persaingan dengan suatu golonganatau golongan-golongan lain yang mempunyai pandangan yang berbeda.Selanjutnya pakar ilmu politik lainnya, Giovani Sartori, berpendapat bahwa partai politik adalah suatu kelompok politik yang mengikuti pemilihan umum dan melalui pemilihan umum itu, 
mampu menempatkan calon-calonnya untuk menduduki jabatan-jabatan politik ${ }^{1}$

Secara operasional lebih teknis, sebagaimana digambarkan oleh undang-undang (UU) Politik, yaitu UU No. 2/2008 tentang Partai Politik, menegaskan bahwa pengertian partai politik adalah organisasi yang bersifat nasional dan dibentuk oleh sekelompok warga negara Indonesia secara sukarela atas dasar kesamaan kehendak dan cita-cita untuk memperjuangkan dan membela kepentingan politik anggota, masyarakat, bangsa, dan negara serta memelihara keutuhan Negara Kesatuan Republik Indonesia berdasarkan Pancasila dan Undang-Undang Dasar Negara Republik Indonesia Tahun $1945 .^{2}$

\section{B. FUNGSI PARTAI POLITIK}

Fungsi utama dan pertama partai politik adalah mencari dan mempertahankan kekuasaan guna mewujudkan program-program yang disusun berdasarkan ideologi tertentu. Adapun cara yang digunakan oleh suatu partai politik dalam sistem politik demokrasi dalam rangka mendapatkan dan mempertahankan kekuasaan ialah dengan ikut serta dalam pemilihan umum.

Partai politik baik dalam sistem politik apapun, apalagi sistem politik demokrasi, ia pasti harus melaksanakan sejumlah fungsi, di antaranya sosialisasi PolitikYang dimaksud dengan sosialisasi politik adalah proses pembentukan sikap dan orientasi politik para anggota masyarakat, melalui proses sosialisasi politik inilah para anggota masyarakat memperoleh sikap dan orientasi terhadap kehidupan politik yang berlangsung dalam masyarakat. Proses ini berlangsung seumur hidup, baik diperoleh secara sengaja (pendidikan formal, nonformal, informal) maupun secara tidak sengaja

\footnotetext{
${ }^{1}$ Giovani Sartori,Parties and Party Systems: A Framework for Analysis,1976,Cambridge University Press, hal.3

${ }^{2}$ Giovani Sartori,Parties and Party Systems: A Framework for Analysis,1976,Cambridge University Press, hal.3
} 
(pengalaman sehari-hari dalam keluarga, teman bermain, tetangga, dalam kehidupan bermasyarakat).Rekrutmen PoltikPengertian rekrutmen politik adalah seleksi dan pemilihan atau pengangkatan seseorang atau seke-lompok orang untuk melaksanakan sejumlah peranan dalam sistem politik pada umumnya dan pemerintahan pada khususnya, semakin besar fungsinya manakala partai politik itu mayoritas di parlemen, sehingga berwenangmembentuk pemerintahan dalam sistem demokrasi.

\section{a. Partisipasi Politik}

Partisipasi politik adalah kegiatan warga negara biasa dalam mempengaruhi proses pembuatan dan pelaksanaan kebijakan publik (public policy) dan dalam ikut menentukan pimpinan pemerintahan melalui suatu pemilihan umum yang teratur dan demokratis. Kegiatan dimaksud di antaranya mengajukan tuntutan, mem-bayar pajak, melaksanakan keputusan, mengajukan pemimpin, dan men-dukung calon pemimpin. Partai politikjuga membuka kesempatan, mendorong dan mengajak para anggota dan anggota masyarakat yang lain untuk menggunakan partai politik sebagai saluran kegiatan mempengaruhi proses politik. Dengan demikian, partai politik merupakan wadah partisipasipolitik.Pemadu KepentinganUntuk menampung dan mema-dukan berbagai kepentingan yang berbeda bahkan bertentangan, maka partai politik dibentuk. Kegiatan menampung, menganalisis, dan me-madukan berbagai kepentingan yang berbeda bahkan bertentangan menjadi berbagai alternatif kebijakan publik kemudian diperjuangkan dalam proses pembuatan dan pelaksanaan keputusan politik. Itulah yang dimaksud dengan fungsi pemaduan kepentingan.

b. Komunikasi Politik

Komunikasi politik adalah proses penyampaian informasi mengenai politik dari pemerintah kepada warga masyarakat, dan dari warga masyarakat kepada pemerintah. Dalam konteks ini partai politik berfungsi sebagai komunikator politik, tidak terbatas

menyampaikan segala keputusan dan penjelasan pemerintah kepada warga masyarakat tetapi juga menyampaikan aspirasi dan kepentingan berbagai kelompok masyarakat kepada peme-rintah. Keduanya dilaksanakan oleh partai politik dalam sistem politik demokrasi.Pengendalian KonflikDalam negara demokrasi, setiap warga 
negara atau kelompok masyarakat berhak menyampaikan dan memperjuangkan aspirasi dan kepentingannya sehingga konflik merupakan gejala yang sukar dielakan. Sistem politik hanya akan mentolerir konflik yang tidak menghancurkan dirinya, dengan demikian perma-salahannya bukan menghilangkan konflik itu, melainkan mengendalikan konflik melalui lembaga demokrasi untuk mendapatkan penyelesaian dalam bentuk keputusan politik. Partai politik sebagai salah satu lembaga demokrasi berfungsi untuk bisa mengendalikan konflik melalui cara dialog dengan pihak-pihak yang ber-konflik, menampung dan memadukan berbagai aspirasi dan kepentingan dari pihak-pihak yang berkonflik dan mem-bawa permasalahan kedalam musya-warah badan perwakilan rakyat (DPR) untuk mendapatkan penyelesaian berupa keputusan politik (kompromidi antara para wakil rakyat yang berasal dari partai-partai politik).

c. Kontrol Politik

Kontrol politik adalah kegiatan untuk menunjukkan kesalahan, kelemahan, dan penyimpangan dalam pengertian bahwa suatu kebijakan(formulasi, implementasi) yang dibuat dan dilaksanakan oleh pemerintah. Pada saat melakukan suatu kontrol politik atau pengawasan harus ada tolok ukur yang jelas sehingga kegiatan itu bersifat relatif obyektif. Adapun tolok ukur suatu kontrol politik berupa nilai-nilai politik yang dianggap ideal dan baik (ideologi) yang dijabarkan kedalam berbagai kebijakan (policy) atau perundang-undangan. Tujuan suatu kontrol politik adalah untuk meluruskan kebijakan terutama pelaksanaan kebijakan yang dianggap menyimpang dan memperbaiki yang keliru, sehingga kebijakan dan pelaksanaannya sejalan dengan tolokukur tersebut. Fungsi kontrol ini adalah merupakan salah satu mekanisme politik dalam sistem politik demokrasidalam rangka memperbaiki dan memperbaharui dirinya secara terus menerus $^{3}$

\footnotetext{
${ }^{3}$ Giovani Sartori,Parties and Party Systems: A Framework for Analysis,1976,Cambridge University Press,hal.3
} 


\section{Partisipasi dan keterlibatan partai politik dalam pilkada}

Pilkada serentak wajib diselenggarakan pada tanggal 9Desember 2015 untuk daerah yang masa jabatan kepala daerahnyaberakhir mulai Januari 2015 hingga Juni

2016. Pilkada serentakgelombang pertama di Indonesia terdiri dari 9 (sembilan) provinsi dan 260 (Dua Ratus Enam Puluh) kabupaten/kota. Artinya, sekitar 50\%dari total 5371jumlah provinsi dan kabupaten/kota di Indonesia akanmelaksanakan pilkada serentak gelombang pertama.Pilkada serentak yang diselenggarakan akhir tahun inimerupakan terobosan politik penting dalam perkembangan demokrasi. Ini merupakan bagian dari penataan sistem politik yang terus berkembang sejak era reformasi, yang menempatkan daerah sebagai entitas otonom dan mandiri. Sejak digelar pada pertengahan tahun 2005 hingga sekarang, pilkada di Indonesia telah memperkuat basislegitimasi kepemimpinan politik lokal yang demokratis. Bagaimanapun fenomena pilkada, telah menjadi potret praktik demokrasi politik, di samping pileg dan pilpres. Partai politik memiliki posisi penting dalam pencalonan kandidat pemimpin daerah,meskipun dimungkinkan lewat jalur perseorangan ataupun independen. Walaupun demikian, sebagian besar kandidat maju melalui jalur parpol, baik diajukan partai pengusung sendiri maupun koalisi. Oleh sebab itu, penting mencermati perkembangan parpol dewasa ini.

Pada proses pelaksanaannya banyak dampak yang akan ditimbulkan dari pilkada serentak ini, baik dampak positif maupun negatif. Selama ini, pilkada yang tidak serentak dari sisi penganggaran dinilai tidak efisien dan boros termasuk dalam penggunaan sumber daya manusia. Selain itu dari sisi politik, Pilkada yang tidak serentak juga memiliki kecenderungan terjadinya kecurangan melalui mobilisasi massa antardaerah. Sedangkan dengan diadakan pilkada serentak dinilai lebih efektif dan menghemat biaya anggarannya. Pilkada serentak bermanfaat mengurangi kecurangan melalui mobilisasi massa dari daerah lain dan migrasi kekuatan para cukong yang ingin bermain dalam pilkada. Jika hal tersebut terjadi maka apayang dihasilkan oleh pilkada tak serentak adalah hasil dari proses negosiasi kepentingan. Melalui pilkada serentak 
inilah secara teoritis berupaya untuk mencegah hal-hal negatif tersebut.

Namun demikian, di balik manfaat pilkada serentak juga terdapat potensi kekhawatiran bila penyelengaraannya dinilai tidak demokratis. Pilkada serentak rawan dengan konflik serentak. Contoh yang terjadi saat pilkada 2015 ini adalah perihal munculnya kandidat tunggal pada tujuh daerah yaitu Kota Mataram (Provinsi NTB), Kabupaten Timor Tengah Utara (NTT), Kabupaten Tasikmalaya (Jawa Barat), Kota Samarinda (Kalimantan Timur), dan KabupatenBlitar (Jawa Timur), Kota Surabaya, dan Kabupaten Pacitan (Jawa Timur).2 Tentu konflik serentak tersebut memiliki dampak yang lebih besar. Pada daerah yang telah memiliki dua atau tiga calon kandidat kepala daerah pun masih berpeluang munculnya kandidat tunggal karena proses verifikasi belum selesai. Untuk itu penyelengaraan pilkada serentak juga perlu dipastikan dengan aturan main dan kepastian hukum sehingga tidak menimbulkan konflik yang skalanya lebih masif.

Konflik Parpol Partai politik saat ini juga memiliki pengaruh besar dalam pelaksanaan pilkada tersebut, sesuai dengan fungsi partai politik untuk memperjuangkan aspirasi masyarakat melalui pemilihan umum, baik di legislatif maupun eksekutif. Pemilihan kepala Daerah secara langsung selanjutnya diwujudkan dengan disusunnya Undang-Undang Nomor 32 Tahun 2004. Menurut Undang-Undang, Nomor 32 tahun 2004, Kepala Daerah adalah Kepala Pemerintah Daerah yang dipilih secara demokratis. Pemilihan secara demokratis terhadap Kepala Daerah tersebut dilakukan oleh rakyat secara langsung. Kepala Daerah dan Wakil Kepala Daerah dipilih secara langsung oleh rakyat yang persyaratan dan tata tata caranya ditetapkan dalam peraturan perundang-undangan. Pasangan calon Kepala Daerah dan Wakil Kepala Daerah dapat dicalonkan baik oleh partai politik atau gabungan partai politik peserta pemilu yang mempunyai sejumlah kursi tertentu dalam DPRD dan atau memperoleh dukungan suara dalam pemilu legislatif dalam jumlah tertentu.

Peran partai politik tampak dalam Undang-Undang No 8Tahun 2015 yang merupakan revisi Undang-Undang No 1 Tahun 2014 tentang Pilkada Gubernur, Bupati dan Walikota. Dalam UU diatur, partai politik maupun gabungan partai politik 
dapatmengajukan bakal calon kepala daerah bila memiliki 20 persen kursi di DPRD maupun 25 persen suara sah perolehan dalam pemilu legialastif DPRD 2014. Artinya bila partai politik tersebut memiliki kursi lebih dari 20 persen di DPRD ataupun perolehan suara lebih dari 25 persen, dapat mengajukan sendiri. Namun bila tidak, maka harus bergabung dengan partai lainnya agar memenuhi jumlah kursi 20 persen atau 25 persen suara untuk dapat mengajukan bakal calon kepala daerah. Untuk mengajukan nama bakal calon tersebut, tentunyapartai politik harus memiliki kepenguruan yang sah.3

Secara umum sistem kepartaian di Indonesia tak dapat dilepaskan dari eksistensi kepengurusan di pusat. Solid tidaknya kepengurusan pusat parpol dapat berpengaruh pada pilkada. Bila rezim pilkada serentak identik dengan pemilu nasional, eksistensi dan peran maka kepengurusan parpol dari pusat sangat menentukan.Dalam kaitan inilah, kita melihat hubungan tidak langsung antara kedewasaan parpol dalam memperkuat soliditas dan kelembagaannya.Karena itulah, realitas konflik di parpol, merupakan tantangan, tidaksaja bagi masa depan parpol itu, tetapi juga dalam konteks masa depan kepemimpinan lokal. Beberapa partai pun sekarang ada yang mengalami konflik kepengurusan. Hal inilah yang tengah dialami Partai Persatuan Pembangunan (PPP) dan Partai Golkar. PPP dilanda konflik kepengurusan, setelah Pengadilan Tata Usaha Negara (PTUN) Jakarta menunda keabsahan kepengurusan PPP Muktamar Surabaya yang dipimpin M. Romahurmuziy. PTUN memenangkan gugatan mantan Ketua Umum PPP SDA dan Ketua Umum PPP versi Muktamar Jakarta Djan Faridz. Kini kasusnya tengah diajukan banding kePengadilan Tinggi TUN. Sementara di Partai Golkar, Pengadilan Jakarta Utara telah mengeluarkan putusan sela untuk membekukan sementara Kepengurusan Munas Jakarta Agung Laksono, dan memenangkan gugatan Ketua Umum Partai Golkar versi Munas Bali Aburizal Bakrie. Kini kedua pihak tengah sidang dalam perkara dualisme kepengurusan di Pengadilan Tata Usaha Negara (PTUN).

Sengketa internal partai politik tersebut berpotensi besar menyeret pilkada dalam konflik yang berlarut-larut, bila kedua belah pihak bersengketa memaksa ikut serta, sementara tidak ada kepastian hukum pengurus mana yang berhak mengikuti pilkada tersebut. KPU sendiri sebelumnya, berdasarkan undang-undang menyatakan partai 
politik yang sah adalah yang terdaftar di Kementerian Hukum dan HAM. Seiring dengan perkembangan konflik, konflik parpol tersebut juga didorong oleh persaingan Koalisi Merah Putih dan Koalisi Indonesia Hebat. DPR yang dikuasai mayoritas KMP, setelah gagal memaksa KPU untuk mengubah peraturan terkait keabsahan pengurus partai politik yang turut dalam pilkada, mengeluarkan jurus revisi UU Partai Politik. DPR melalui Komisi II tengah mengajukan klausul perubahan undang-undang agar pengurus partai politik yang berhak ikut serta dalam pilkada adalah berdasarkan putusan hukum yang keluar sebelum pendaftaran bakal calon pilkada, meskipun belum final dan mengikat. Kawal Pilkada dalam pandangan sejumlah aktivis prodemokrasi, perkembangan konflik partai politik saat ini telah membuat KPU dalam posisi dilematik dan membahayakan penyelenggaraan serta kualitas dari pemilihan kepala daerah secara serentak. Selain itu juga berpotensi terjadinya konflik berlarut-larut di daerah. Hal-hal di atas hanya sebagian permasalah ${ }^{4}$

\footnotetext{
${ }^{4}$ Giovani Sartori,Parties and Party Systems: A Framework for Analysis,1976,Cambridge University Press,hal.3
} 